\title{
Governance in banks using not-for-profit organisations to deliver their corporate social responsibility
}

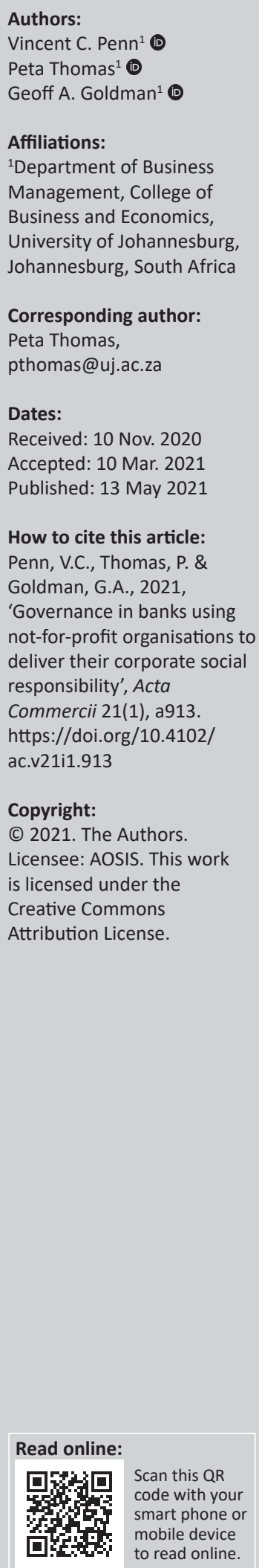

Orientation: Little exists in academic literature on the governance framework underlying the relationship between not-for-profit organisations (NPOs) delivering corporate social responsibility (CSR) on behalf of donors.

Research purpose: The purpose of this study was to examine community value created by four leading South African retail banks through their CSR initiatives implemented by NPOs.

Motivation for the study: This study was motivated by the need to assess banks' public disclosure of their CSR efforts in terms of community upliftment.

Research design, approach and method: A qualitative, exploratory approach was adopted, using content analysis of CSR projects and bank NPOs, which have been given as public disclosure on the banks' websites. Purposeful, one-on-one, interviews were then undertaken with NPOs and the CSR community recipients and content analysis was again used to identify key themes.

Main findings: The findings of this study indicate that banks do not adopt standardised reporting to the Johannesburg Stock Exchange (JSE) and therefore the measure of success for community upliftment is impossible to gauge.

Practical/managerial implications: This study proposes a need for the development of a standardised CSR measurement framework for use by the JSE.

Contribution/value-add: The study highlighted the critical role of CSR governance in creating community upliftment.

Keywords: community development; corporate social responsibility; CSR governance framework; financial institutions; South Africa.

\section{Introduction}

Corporate social responsibility (CSR) is interpreted differently by different firms, depending on each firm's level of development, awareness of the importance of CSR and the firm's geographic location (Hąbek \& Wolniak 2015). Consequently, despite the wealth of literature on the subject, CSR remains a broad, complex and continually evolving concept encompassing a variety of ideas and practices. In the context of South Africa (SA), very little is known about CSR interventions from the perspective of a CSR donor working through a not-for-profit organisation (NPO) to uplift a community. In this study, the donors are four South African retail banks with a significant footprint in communities across the country. Not-for-profit organisations cooperate with banks to implement the CSR interventions in the recipient communities. In South Africa, as CSR has become incorporated into the business goals of banks, organisations have acknowledged their obligation to safeguard the interests of the communities and the society in which they operate. Fortunately, CSR is now widely considered an operational reality that can gain competitive advantage over other firms. Banks have therefore been willing to implement various interventions to uplift these communities (Nwagbara \& Reid 2013). The purpose of the current study was to explore the governance framework underlying the relationship between the bank and the NPO in implementing the bank's CSR initiative.

\section{Literature review}

Corporate social responsibility strategies are most successful when implemented concurrently with the firm's own business objectives - as part and parcel of its own profit-making 
activities (Johannesburg Stock Exchange [JSE] 2021; Pearce \& Robinson 2011). Numerous studies support the business case for CSR, indicating that stakeholder groups reward firms, which engage in CSR initiatives, particularly if these activities are comprehensively and transparently communicated in the firm's reporting (Klettner, Clarke \& Boersma 2014). Like any other strategy for growing a business, CSR can contribute to the profit of a company through the adoption of integrated, triple bottom-line reporting (social, environmental and financial) (Ganescu 2012; International Integrated Reporting Council 2013; Masocha \& Fatoki 2018). This implies that the gains derived from CSR, just like financial gains, should be planned with clearly measurable outcomes (Basu \& Palazzo 2008). Consequently, the integrated reporting of the company should offer (International Integrated Reporting Council 2021:

[C]oncise communication about how an organization's strategy, governance, performance and prospects in the context of its external environment, can lead to the creation of value over the short, medium and long term. (p. 10)

Good corporate citizenship (CC) can clearly communicate a firm's acknowledgement of its responsibilities as an institution responding to societal needs (Carroll 1979; Masocha \& Fatoki 2018). This can be clearly demonstrated through the adoption of triple bottom-line reporting (social, environmental and financial), which communicates (1) what societal value the firm's CSR activities create (Wartick \& Cochran 1985), (2) the manner in which the firm achieves its social responsiveness (Clarkson 1995) and (3) how inclusive its CSR stakeholder engagement is (Strand \& Freeman 2013).

Understanding the strategic planning and control processes measuring the value of CSR activity is essential in establishing the authenticity of a CC (Institute of Directors in Southern Africa 2016; Porter \& Kramer 2011). To track the value of CSR, the firm must establish a framework with key performance indicators, which can be used to review the value created by CSR (Van Dyk \& Fourie 2015).

Measurement of CSR value for reporting is particularly complex for intangible value creation such as community goodwill; it is, however, important for a firm seeking to consolidate its CC worthiness (Sridhar \& Jones 2012). Measurement in a quantifiable manner conveys to internal and external stakeholders the sustainability of a firm's triple bottom-line actions. The Brundtland Report (1987:5) explained that a firm's sustainable development must meet 'the needs of the present generations without compromising the ability of the future generations to meet their own needs'. Sustainability is thus essential; all firms, whether private or public, need to adopt triple bottom-line management in every strategic decision if the needs of future generations are to be met.
In South Africa, the JSE has affirmed the importance of sustainability in national community development by introducing a measurement index allowing stakeholders to evaluate the financial and social responsibility of firms listed on the JSE (2021). This socially responsible investment (SRI) index is a reporting mechanism by which the sustainable manner in which a firm behaves can be publicly monitored through its environmental, social and governance (ESG) reporting (JSE 2014). The JSE (2014) observed that the SRI promotes the philosophy of firm sustainability, reinforced by good corporate governance. In South Arica, embracing SRI principles by a JSE-listed firm is considered to have an overall positive effect on the country's environmental, social and economic spheres (Waddock 2010). Within each ESG sphere, firms can measure how they integrate the ESG criteria into their daily governance frameworks used for policy-making, strategy formulation, performance management and integrated reporting (JSE 2021). Ethical behaviour by listed firms is encouraged, using past integrated performance reporting as a basis for future shareholder investment decisions (Ogbuka \& Fakoya 2016). The SRI approach must look at financial investment targets with the parallel intention of yielding distinctive social returns.

As South African firms strive to solve complex business sustainability challenges whilst at the same time seeking to meet societal challenges, NPOs can assist donors with CSR delivery. This is because they are strategically placed through their outreach activities within local communities (Van Dyk \& Fourie 2015). Working in partnership with donor firms exposes NPOs to what happens 'upstream' in the donor firm in terms of its role as a strategic partner of CSR delivery and the CSR project planning. The NPO also becomes uniquely involved in the CSR delivery 'downstream' with the recipient communities in terms of implementation, monitoring and control (Van Dyk \& Fourie 2015; Wells 2012). The NPO thus serves as a valuable bridging mechanism between the donor and the community (Penn, Thomas \& Goldman 2019). This bridging role of the NPO should therefore be aligned with JSE rules with regard to planning and delivering triple bottom-line outcomes. Johannesburg Stock Exchange-listed firms use shareholder resources to attain their CSR goals through the NPOs; transparency in reporting on the governance and value creation of these firm-NPO relationships is therefore essential.

Governance of a JSE-listed firm, such as a retail bank, is affected by the JSE SRI requirements. Banks must therefore establish guiding frameworks of CSR policies and processes, together with recommendations for their application when embarking on CSR projects (Badewi 2016; Wells 2012). Governance thus becomes vital for establishing accountability at all levels of a CSR project, beginning from project initiation to project closure and aligning project objectives with the overall firm strategy (Project Management Institute [PMI] 2017). Establishment of a governance framework to facilitate a CSR community project paves the way for an optimised community recipient experience, 
reducing firm input waste (ineffectual use of money and human capital) in using shareholder resources to engage with communities.

A governance framework provides a structure for projects defining and setting guidelines for the enforcement of standardising processes. Using a project governance framework makes it easy to analyse decisions and evaluate all project milestones (Badewi 2016). Such a structure provides accountability for managerial decision-making, ensuring alignment of project objectives with the strategy of the organisation (PMI 2017). The lack of governance framework results in the lack of project stage-to-stage coherence, lack of transparency of actions and an overall lack of accountability (Badewi 2016). Adopting a good project management framework and methodology for optimum productivity by the NPO is essential if the funding obtained from the donors is to be used to create maximum value for recipient communities. A CSR project management framework could be viewed as a suite of tools, processes and templates to facilitate planning, implementation, monitoring, control and closure of a project (Vaníčková 2017). Naybour (2010) observed that such a framework can standardise processes to accurately measure a project's life cycle, as required by triple bottom-line reporting. The JSE does not specify a specific management framework that firms such as South African retail banks should use to report on social activities.

Several widely applied project management frameworks exist to establish the success of a project (International Standards Organisation [ISO] 260002010 ; Vaníčková 2017). Seven complementary themes were adapted from these frameworks for use in this study. These were used to assess the extent of the ESG governance and accountability of CSR project sustainable reporting. This involved (1) establishing how stakeholder engagement (NPO, bank and community recipient) was managed and reported, (2) establishing how needs analysis was conducted to identify the needs of the community, (3) defining the desired outcomes from the bank, NPO and community recipient at project initiation, (4) planning and implementing the NPO project with the bank and the community, (5) monitoring and controlling each phase of the project, (6) project closure and post-implementation monitoring and (7) overall project governance.

\section{Method}

There is little research available on the rigour of the governance relationship between donor firms and NPOs with regard to transparent, standardised management processes for JSE-listed firms working through NPOs. As such, the nature of this study is exploratory (Saunders, Lewis \& Thornhill 2007) and interpretivist (Guba \& Lincoln 1994). Five JSE-listed retail banks collectively hold $89.4 \%$ of the South African total banking assets (South African Reserve Bank 2019/2020:19). These banks were selected through convenience sampling as they were deemed to represent sustainable firm behaviour in their reporting. These banks have extensive footprints throughout all urban and rural South African communities. This footprint implies that the banks have an obligation to act as good corporate citizens within their communities.

A preliminary review of information on the banks' websites was conducted. As JSE-listed firms, the banks were legally bound to have full disclosure of all NPO CSR project information on their websites for all stakeholders to read. To establish the extent of disclosure, the study first examined the integrated reports of the banks. Each report should describe the banks' project governance for every NPO-run CSR project. One bank was eliminated as there was limited information on its CSR initiative, which had only been running for a couple of months. For the remaining four banks, the seven themes were used to evaluate the banks' achievement of ESG goals.

The websites were used to gather NPO project details (the name of the NPO and type of project) as reported by the banks over a 3-year period from 2014 to 2016. This period was selected as it would allow the year-end integrated reports incorporating CSR activities to be reflected. Corporate social responsibility projects of 13 months or longer would give the bank and the NPO ample time to apply standardised processes to measure inputs and outputs and publish them in the public domain.

Of the 11 NPO-bank relationships that fitted the above inclusion criteria, it emerged that all CSR projects were similar insofar as they provided various upskilling through training to community recipients. This was a valuable initiative as such training could uplift recipients, giving them a better chance of survival. Contact details for six of the NPOs could not be found on the banks' websites, so Google was used to find current telephone numbers and physical addresses of these NPOs. One-on-one, semi-structured interviews were conducted with a senior NPO project manager for each of the 11 NPOs. The interviews explored how and why the CSR project systems were measured. The interviews also delved into the tripartite NPO-bank-recipient relationship to understand what NPO structures were in place in terms of inclusion, transparency and standardisation to govern these relationships (Edmonds \& Kennedy 2013). Participants were encouraged to describe their experiences as the NPO responsible for the donor's CSR initiative (Edmonds \& Kennedy 2013; Guba \& Lincoln 1994).

The interviews were recorded and verbatim transcripts were made immediately after each interview. The input from each NPO was used in the subsequent interview to probe certain aspects more thoroughly (Creswell 2015). Direct content analysis was used to interpret the findings using the seven themes, together with the secondary literature on JSE reporting standards (Babbie \& Mouton 2001).

Before commencing the interviews, the purpose of the study was explained to the participants. They were assured that confidentiality and anonymity would be maintained and 
were informed that they could opt out of the interview at any point (Salkind 2012).

\section{Ethical considerations}

Ethical approval to conduct the study was obtained from the CBE Research Ethics Committee of the University of Johannesburg (approval no. 2018BM04).

\section{Results and discussion}

The bank's websites revealed significant variations in the amount of transparency of their CSR reporting on the 11 CSR initiatives. Only one bank had a dedicated CSR sustainability report on its website. The remaining three had short sections in their integrated annual reports containing a high-level review of their NPO-run CSR project. Descriptions of the CSR projects, specific pre-project objectives and expected outcomes were found to be extremely limited for all four banks. Typically, the banks declared gross financial contributions made to the CSR project; however, the value for the community was not specified, neither in the short term nor in the longer term. Little to no detail was reported on the bank's relationship with their NPO or the NPO's relationship with the community.

It was thus concluded that the banks were not reporting transparently or accurately enough, in line with JSE ESG criteria. This is an opportunity lost to demonstrate good CC in gaining future shareholder and stakeholder support (Friede, Busch \& Bassen 2015). These findings emphasise that much still needs to be done to meet the seminal CSR recommendations of Bowen (1953), who suggested the use of social audits of CSR initiatives to corroborate claims made by firms in the public domain. Similar recommendations have been made by Ackers and Eccles (2015).

Theme 1 established the scope of stakeholder engagement. The NPOs indicated that they leveraged different communication channels to establish community needs. Some had established networks of recruiters to channel possible community beneficiaries to the NPO. Van Dyk and Fourie (2015) described NPOs as a bridge between the donors and the recipient communities. This is because an effective NPO has grassroots, community contacts with a good understanding of the realities of the recipient community's needs. For example, one of the 11 NPOs had been providing training in the same community for 35 years, another for 23 years, a third one for 19 years and the remainder for periods of between 5 and 15 years. This has built intangible value for the community in terms of trust based upon past delivery of benefits by the NPO. Community members approached the NPOs with confidence when they needed NPO services. This finding highlights the need for mutual trust between firms and the societies in which they operate. Interdependency must therefore exist to create value (Bozicnik \& Mulej 2010; Hinson \& Ndlovu 2011; ISO 26000 2010; McDonagh \& Prothero 2014; Serra \& Kunc 2015). This is an important role that NPOs play for the donor bank. Serrat (2009) asserted that stakeholder's trust is an intangible CSR project asset as it supports high levels of stakeholder involvement. The NPOs indicated that the banks, when accepting their proposals, did not conduct community needs analysis themselves nor did they define any processes for how bank-NPO, NPOcommunity and bank-community engagement would be managed. The bank left these for the NPO to organise. Saleh, Zulkifli and Muhamad (2010) claimed that firms often engage in 'window-dressing' exercises with their CSR initiatives, neglecting to thoroughly integrate CSR into their business strategy.

Theme 2 reviewed the extent to which a needs analysis was carried out. Due diligence (DD) can incorporate a needs analysis to investigate all aspects of a proposed CSR project to facilitate informed decision-making (Cassimon, Engelen \& Liedekerke 2016; Panda 2013). During DD, stakeholder needs should be analysed as the DD authenticates the NPO proposal to the bank (Chawla \& Sehgal 2017) and verifies the needs of potential CSR recipients. The NPOs were not aware whether the banks had carried out DD on each NPO and evidence of this was not available on the banks' websites. The NPOs should have enquired as to what DD obligations they needed to fulfil to recruit the bank as a funder. This is because South African NPOs are legal entities and therefore need to abide by South African company law in CSR activities, which would guide the purpose of the future bank-NPOcommunity relationship (Kini, Dura \& Acosta-Grimes 2018), reducing chances of CSR project failure.

Theme 3 explored the extent to which the CSR projects delivered to desired outcomes. All CSR project stakeholders should be able to describe the 'what' and the 'how' of reaching their intended outcomes (Masocha \& Fatoki 2018; Nwagbara \& Reid 2013). Contracts should define agreed CSR project management principles between stakeholders (Samuel \& Mqomboti 2017). To find out the 'what' and 'how', the NPOs reported that the banks asked the NPOs to organise conferences/workshops, for which the banks paid, with potential community CSR recipients to further the banks' understanding. The banks, however, were reported by the NPOs to use these opportunities to showcase their banking products, looking for new client acquisitions, rather than delving into community needs for the CSR intervention. All four banks left it to their NPOs to define CSR project details. Often in CSR, the firm separates itself from the moral responsibility to society for how it makes its business decisions (Institute of Directors in Southern Africa 2016; Richardson \& Cragg 2010; Zarezankova-Potevska \& Potevska-Kolevska 2017). This view is supported by Ackers and Eccles (2015) and Pucheta-Martínez, Bel-Oms and Rodrigues (2019), who suggested that CSR disclosures should be verified by externally audited stakeholder assurance reports, thereby ensuring the integrity of ESG disclosures (Ganescu 2012).

Theme 4 of the data analysis focused on the planning and implementation of the CSR projects as research indicates that 
it is crucial to leverage knowledge created from past projects for future projects (Serrat 2009). Weerawardena, McDonald and Mort (2010) opined that NPOs seeking to ensure their own sustainably have a major influence on NPOs, compelling them to adopt a strategic approach in the way they plan and implement projects. Yet this study found that for all 11 NPOs there was no agreement or contract between the bank and the NPO with regard to their roles as project partners. The full value for the CSR donor (the bank) as a profit-orientated enterprise will not be realised unless the NPO and bank agree at project inception stage as to how to communicate, both through the CSR project recipients and directly through the NPO to wider stakeholder communities. Speaking of the bank-NPO project to their communities, recipients can create considerable word-of-mouth marketing for funders. Gazdecki (2018) asserted that a contract will clarify each area of delivery for optimum productivity, including communication. Lack of a communication policy supports the findings of Ganescu (2012) and Masocha and Fatoki (2018) that firms engaging in CSR activities, which are motivated purely by legislation such as JSE requirements, may unwittingly limit their ability to leverage maximum future stakeholder value.

Theme 5 related to the presence of monitoring and control and it was clear that formalised reporting structures and realistic evaluation of the project outcomes were not contractually defined to the NPOs by the banks. This could reflect a lack of real commitment to the CSR (Serrat 2009). Whilst the JSE requires compliance with ESG reporting (Institute of Directors in Southern Africa 2016; JSE 2021), neither triple bottom-line reporting guidelines nor the SRI index seeks to authentically analyse the value created by CSR initiatives. This means that there is no 'tick box' allowing firms to report on their CSR activities. It is for this reason that there should be well-articulated and measurable project objectives, together with reporting on the intangible positive changes that each initiative intends to bring to the lives of beneficiaries. Project monitoring that runs continuously from project initiation until project closure is therefore vital (PMI 2017; Zohoori et al. 2019). ISO 26000 (2010) stated that the project deliverer (NPO) must explain the need for documented project strategies and objectives to the recipient if the NPO has to reflect real commitment to optimal CSR value to the community. This study found that actual implementation of monitoring strategies, which evaluate the transformation of inputs to outputs, is limited, potentially letting down recipients in terms of the quality of the final outcomes. Lack of NPO control may make it difficult to continue an important CSR intervention in terms of gaining future funders as past projects are not well documented. These findings support research by the International Institute of Business Analysis (IIBA) (2015) and PMI (2017), which indicate that all business objectives, both tangible and intangible, should be clearly defined. In this case, the donor banks would need to clearly define monitoring and reporting processes, as required by ESG reporting, to the NPO. The NPO, on the other hand, would also need to take more appropriate action to monitor and control their projects even if the donor bank fails to do so. This is achieved by agreeing on project requirements so that the final product yields the desired level of satisfaction for all the stakeholders.

Theme 6 dealt with the closure and post-implementation monitoring. Ten of the NPOs interviewed indicated that they needed funding post-project to oversee the continuation of the initiative, reporting on success or failure to the donors, who would then, in turn, be able to report to their own stakeholders. This finding agrees with that of Weerawardena et al. (2010) and IIBA (2015). The funding period for which the bank is ready to commit funds is often unclear according to the 11 NPOs, and this has a direct effect on the manner in which the NPOs can plan their intervention for a community. The NPOs also indicated that this lack of clear definition from banks in terms of funding time has a psychological effect on the NPO as they are never quite sure when they should start looking for another funder. With regard to project closure, nine NPOs indicated that they failed to thoroughly document the project results or reflect on what went right or wrong on a project. This, they claimed, was because of a lack of time because they never knew when they had to leave a current project at the will of the donor and move on to the next project. It was only after documenting project results that a project retrospective can be conducted, for use in future projects (McClory, Read \& Labib 2017). Six NPOs indicated that there was no 'breather' period at the end of each bank's CSR project as the donor bank cut the funding when a project concluded, often moving CSR work to another NPO or to a completely new CSR sponsorship area that the NPO had to familiarise itself with. This means that NPOs may not be aware of postproject community recipient challenges after the NPO leaves. All NPOs agreed that project ending did not leave them enough time to plan for ways to overcome challenges learnt from the last project (McClory et al. 2017). Consequently, a cycle of incomplete project requirement specifications continues. Final CSR project reports were requested from each NPO by the researcher, as prescribed in the code of good practice for South African NPOs on registering an NPO (Department of Social Development 2000). However, none of the NPOs had such a report although NPO registration in SA requires the NPO to have an honest, open relationship with its supporters.

Theme 7, relating to project governance, indicated that this aspect should be an established framework within which project decisions are made. The NPO participants clearly indicated that they did not understand what governance processes were required from the donor banks. This finding casts the donors in an unfavourable light given the recommendations made by ISO 26000 (2010), requiring all firms to establish governance frameworks. This finding supports those of Wells (2012) who argued that NPOs, particularly in developing countries, are challenged with governance issues. 
The term 'strategic partners' is often used by the banks on their websites to refer to their NPOs, suggesting that the CSR projects were jointly conceived as to what is valuable for a community. The research findings, however, revealed another reality, indicating that the CSR projects were actually initiated by the NPOs, which had identified the opportunity or problem and approached the bank with proposals. Banks should explicitly declare in advance the desired change that each project is intended to bring about. This should be published on the banks' websites, in line with their CSR governance framework. This would help in transparently proving identification and solving the root causes of societal issues. Corporate social responsibility projects should thus be identified and reported on in terms of what the donor intended to achieve as its community obligation, what was actually achieved and full disclosure of the actual value, which was created. At present, NPOs are much more than strategic partners, taking on more responsibility individually than they should because it is the bank, as the JSE-listed firm, which requires the CSR activity. This has been revealed by this study as making NPOs vulnerable to bank actions (such as using the NPO to access communities or removing support funding at will). Not-forprofit organisations rarely have contract with the bank that is aligned with an agreed CSR governance framework. For the NPOs, this is an untenable, long-term situation as it can undermine their own reputation and, therefore, their sustainability. It is clear that the banks do not view sustainability in terms of future generations benefitting from CSR projects; the NPOs indicated that banks do not generally support long-term maintenance of a CSR initiative.

\section{Conclusions}

The preceding discussion suggests that firms that adopt a documented CSR governance framework are able to ensure that money and effort put into CSR initiatives yield maximum value for both shareholders and stakeholders. The purpose of the research was to establish if community value was being created by CSR interventions by banks. This study suggests that in fact the JSE, the NPOs and the banks cannot currently appraise bank CSR value creation by measuring the actual positive change that CSR projects bring to communities. This is because the donor bank, in its relationship with the NPO, fails to use standardised governance systems for CSR delivery and associated reporting. Developing a CSR guiding governance framework helps JSE-listed firms to ensure they actually issue legitimate integrated reporting for stakeholders to peruse. Measurement will lead to reporting transparency on whether societal issues are being fully resolved. Corporate social responsibility project stakeholder inclusivity driven by transparency in reporting will certainly lead to a more socially just economic system serving society. A limitation of this study was that it only dealt with banks and not any other type of JSE-listed company. Further research should be undertaken to explore how JSE-listed companies are applying a CSR project governance framework that includes involving the community recipients as active stakeholders.

\section{Acknowledgements Competing interests}

The authors declare that they have no financial or personal relationships that may have inappropriately influenced them in writing this article.

\section{Authors' contributions}

V.C.P.,P.T. andG.A.G. were involved in the conceptualisation, methodology, investigation, writing of the original draft, review and editing of the article.

\section{Funding information}

This research received no specific grant from any funding agency in the public, commercial, or not-for-profit sectors.

\section{Data availability}

The authors confirm that the data supporting the findings of this study are available within the article.

\section{Disclaimer}

The views and opinions expressed in this article are those of the authors and do not necessarily reflect the official policy or position of any affiliated agency of the authors.

\section{References}

Ackers, B. \& Eccles, N.S., 2015, 'Mandatory corporate social responsibility assurance practices: The case of King III in South Africa', Accounting Auditing \& Accountability Journal 28(4), 515-555. https://doi.org/10.1108/AAAJ-12-2013-1554

Babbie, E. \& Mouton, J., 2001, The practice of social research, Oxford University, Cape Town.

Badewi, A., 2016, 'The impact of project management (PM) and benefits management (BM) practices on project success: Towards developing a project benefits governance framework', International Journal of Project Management 34(4), 761-778. https://doi.org/10.1016/j.ijproman.2015.05.005

Basu, K. \& Palazzo, G., 2008, 'Corporate social responsibility: A process model of sense making', Academy of Management Review 33(1), 122-136. https://doi. org/10.5465/AMR.2008.27745504

Bowen, H., 1953, Social responsibility of the businessman, Harper \& Row Publishers, New York, NY.

Bozicnik, S. \& Mulej, M., 2010, 'Corporate social responsibility and requisite holism Supported by tradeable permits', Systems Research and Behavioural Science 27(1), 23-35. https://doi.org/10.1002/sres.989

Brundtland Report, 1987, Our common future, viewed 11 April 2021, from https:// www.are.admin.ch/are/en/home/sustainable-development/internationalcooperation/2030agenda/un- -milestones-in-sustainable-development/1987-brundtland-report.htm

Carroll, A.B., 1979, 'A three-dimensional conceptual model of corporate performance', Academy of Management Review 4(4), 497-505. https://doi. org $/ 10.2307 / 257850$

Cassimon, D., Engelen, P.J. \& Liedekerke, L.V., 2016, 'When do firms invest in corporate social responsibility? A real options framework', Journal of Business Ethics 137(1), 15-29. https://doi.org/10.1007/s10551-015-2539-y

Chawla, S. \& Sehgal, R., 2017, 'A gap analysis of service quality of internet banking service of State Bank of India in northern India', Journal of Management Research 17(3), 137-145.

Clarkson, M., 1995, 'A stakeholder framework for analysing and evaluating corporate social performance', Academy of Management Review 20(1), 92-118. https://doi. org $/ 10.2307 / 258888$

Creswell, J.W., 2015, A concise introduction to mixed methods research, Sage, Thousand Oaks, CA.

Department of Social Development, 2000, Codes of good practice for South African non-profit organisations, viewed 11 April 2021, from https://www.westerncape. gov.za/other/2004/6/npo_code_of_good_practice.pdf

Edmonds, W.A. \& Kennedy, T.D., 2013, An applied reference guide to research designs, Sage, Thousand Oaks, CA. 
Friede, G., Busch, T. \& Bassen, A., 2015, 'ESG and financial performance: Aggregated evidence from more than 2000 empirical studies', Journal of Sustainable Finance \& Investment 5(4), 210-233, https://doi.org/10.1080/20430795.2015.1118917

Ganescu, M.C., 2012, 'Corporate social responsibility, a strategy to create and consolidate sustainable business', Theoretical and Applied Economics 19(11) 91-106.

Gazdecki, M., 2018, 'Factors of business relationships change in agribusiness input distribution channel: The case of Polish market', IMP Journal 12(3), 567-582. https://doi.org/10.1108/imp-01-2018-0011

Guba, E.G. \& Lincoln, Y.S., 1994, 'Competing paradigms in qualitative research', in N.K. Denzin \& Y.S. Lincoln (eds.), Handbook of qualitative research, pp. 105-117, Sage, Thousand Oaks, CA.

Hąbek, P. \& Wolniak, R., 2015, 'Factors influencing the development of CSR reporting practices: Experts' versus preparers' points of view', Inzinerine Ekonomika-Engineering Economics 26(5), 560-570. https://doi.org/10.5755/ j01.ee.26.5.7690

Hinson, R.E. \& Ndlovu, T.P., 2011, 'Conceptualising corporate social responsibility and corporate social investment: The South African context', Social Responsibility Journal 2(3), 332-346. https://doi.org/10.1108/17471111111154491

Institute of Directors in Southern Africa (IODSA), 2016, King IV report on corporate governance for South Africa, viewed 11 April 2021, from https://cdn.ymaws.com/ www.iodsa.co.za/resource/collection/684B68A7-B 768-465C-8214 E3A007F15A5A/IoDSA_King_IV_Report_-_WebVersion.pdf

International Institute of Business Analysis (IIBA), 2015, A guide to the business analysis body of knowledge, viewed 11 April 2021, from https://cs.anu.edu.au/ courses/comp3120/public_docs/BOKV1_6.pdf

International Integrated Reporting Council (IIRC), 2021, International $<\mid R>$ framework viewed 11 April 2021, from https://integratedreporting.org/wpcontent/ uploads/2021/01/InternationallntegratedReportingFramework.pdf

International Standards Organisation 26000 (ISO), 2010, ISO 26000: Guidance on social responsibility, viewed 11 April 2021, from https://documentation. lastradainternational.org/lsidocs/3078-ISO\%2026000_2010.pdf

Johannesburg Stock Exchange (JSE), 2021, FTSE/JSE Responsible investment index series, viewed 11 April 2021, from https://www.jse.co.za/services/indices/ftsejseresponsible-investment-index-series

Johannesburg Stock Exchange (JSE), 2021, Ground rules: FTSE/JSE Africa index series v7.3, viewed 11 April 2021, from https://www.jse.co.za/sites/default/files/ media/documents/2021-02/FTSE\%20JSE\%20Ground\%20Rules\%20v7\%203\%20 Feb\%202021.pdf

Kini, S.M., Dura, R.T. \& Acosta-Grimes, Z.R., 2018, 'FinCEN issues long-awaited guidance on the customer due diligence rule', Journal of Investment Compliance 19(4), 13-16. https://doi.org/10.1108/JOIC-06-2018-0044

Klettner, A., Clarke, T. \& Boersma, M., 2014, 'The governance of corporate sustainability: Empirical insights into the development, leadership and implementation of responsible business strategy', Journal of Business Ethics 122(1), 1-21. https://doi.org/10.1007/s10551-013-1750-y

Masocha, R. \& Fatoki, O., 2018, 'The impact of coercive pressures on sustainability practices of small businesses in South Africa', Sustainability 10(9), 3032. https:// doi.org/10.3390/su10093032

McClory, S., Read, M. \& Labib, A., 2017, 'Conceptualising the lessons-learned process in project management: Towards a triple-loop learning framework', International Journal of Project Management 35(7), 1322-1335. https://doi.org/10.1016/j. ijproman.2017.05.006

McDonagh, P. \& Prothero, A., 2014, 'Sustainability marketing research: Past, present and future', Journal of Marketing Management 30(11-12), 1186-1219. https:// doi.org/10.1080/0267257X.2014.943263

Naybour, P., 2010, What is a project management framework?, viewed 11 April 2021, from https://www.parallelprojecttraining.com/what-is-a-project-managementframework/.

Nwagbara, U. \& Reid, P., 2013, 'Corporate social responsibility and management trends: Changing times and changing strategies', Economic Insights - Trends and Challenges 65(2), 12-19.

Ogbuka, B.A. \& Fakoya, M., 2016, 'Does consideration of environmental social and governance issues by institutional investors influence responsible investment decision in South Africa?', Journal of Accounting and Management 6(2), 71-90.

Panda, A., 2013, 'Do you know who you are dealing with? Cultural due diligence: What, why and how', VIKALPA: The Journal for Decision Makers 38(2), 1-19.
Pearce, J.A. \& Robinson, R.B., 2011, Strategic management: Formulation implementation and control, McGraw Hill, New York, NY.

Penn, V.C., Thomas, P. \& Goldman, G., 2019, 'The South African firm-NPO-recipient economic development model', Acta Universitatis Danubius Economica (AUDOE) 15(1), 5-18.

Porter, E. \& Kramer, M.R., 2011, 'Creating shared value: How to reinvent capitalism and unleash a wave of innovation and growth', Harvard Business Review 89(1), 63-70.

Project Management Institute (PMI), 2017, A guide to the project management body of knowledge (PMBOK ${ }^{\oplus}$ guide), PMI Publications, Newtown Square, PA.

Pucheta-Martínez, M.C., Bel-Oms, I. \& Rodrigues, L.L., 2019, 'The engagement of auditors in the reporting of corporate social responsibility information', Corporate Social Responsibility and Environmental Management 26(1), 46-56. https://doi. org/10.1002/csr.1656

Richardson, J.R. \& Cragg, W., 2010, 'Being virtuous and prosperous: SRI's conflicting goals', Journal of Business Ethics 92(1), 21-29. https://doi.org/10.1007/s10551010-0632-9

Saleh, M., Zulkifli, N. \& Muhamad, R., 2010, 'Corporate social responsibility disclosure and its relation on institutional ownership: Evidence from public listed companies in Malaysia', Managerial Auditing Journal 25(6), 591-613. https://doi. in Malaysia', Managerial Auditing

Salkind, J.N., 2012, Exploring research, Pearson Education, Hoboken, NJ.

Samuel, O.M. \& Mqomboti, S., 2017, 'Developing an integrative CSR model: Imperative for cultural and consultative dimension', Journal of African Business 18(1), 50-69. https://doi.org/10.1080/15228916.2016.1219174

Saunders, M., Lewis, P. \& Thornhill, A., 2007, Research methods for business students, Pearson Education, London.

Serra, C.E.M. \& Kunc, M., 2015, 'Benefits realisation management and its influence on project success and on the execution of business strategies', International Journa of Project Management 33(1), 53-66. https://doi.org/10.1016/j.ijproman. 2014.03.011

Serrat, O., 2009, 'Building trust in the workplace', Asian Development Bank, viewed 11 April 2021, from https://ecommons.cornell.edu/bitstream/handle/1813/ 87342/Building_Trust_in_the_Workplace.pdf?sequence=1\&isAllowed=y

South African Reserve Bank (SARB), 2019/2020, Prudential authority annual report viewed 11 April 2021, from https://www.resbank.co.za/en/home/publications/ publication-detail-pages/reports/pa-annual-reports/2020/10227

Sridhar, K. \& Jones, G., 2012, 'The three fundamental criticisms of the triple bottom line approach: An empirical study to link sustainability reports in companies based in the Asia-Pacific region and TBL shortcomings', Asian Journal of Business Ethics 2(1), 91-111. https://doi.org/10.1007/s13520-012-0019-3

Strand, R. \& Freeman, R.E., 2013, 'Scandinavian cooperative advantage: The theory and practice of stakeholder engagement in Scandinavia', Journal of Business Ethics 127(1), 65-85. https://doi.org/10.1007/s10551-013-1792-1

Van Dyk, L. \& Fourie, L., 2015, 'Challenges in donor-NPO relationships in the context of corporate social investment', Communication 41(1), 108-130. https://doi.org/10. 1080/02500167.2015.1022563

Vaníčková, R., 2017, 'Application of PRINCE2 project management methodology', Studia Commercialia Bratislavensia 10(38), 227-238. https://doi.org/10.1515/ stcb-2017-0021

Waddock, S., 2010, 'From individual to institution: On making the world different', Journal of Business Ethics 94(1), 9-12. https://doi.org/10.1007/s10551-011-0786-0

Wartick, S.L. \& Cochran, P.L., 1985, 'The evolution of the corporate social performance model', Academy of Management Review 10(4), 758-769. https://doi. org/10.2307/258044

Weerawardena, J., McDonald R.E. \& Mort, G.S., 2010, 'Sustainability of non-profit organizations: An empirical investigation', Journal of World Business 45(4) 346-356. https://doi.org/10.1016/j.jwb.2009.08.004

Wells, P., 2012, 'The non-profit sector and its challenges for governance', Journal of Leadership, Accountability and Ethics 9(2), 83-93. https://doi. org/10.15249/13-2-222

Zarezankova-Potevska, M. \& Potevska-Kolevska, V., 2017, 'Enhancing business ethics through social responsibility', Economic Development (1-2), 265-278.

Zohoori, B., Verbraeck, A., Bagherpour, M. \& Khakdaman, M., 2019, 'Monitoring production time and cost performance by combining earned value analysis and adaptive fuzzy control', Computers \& Industrial Engineering 127(1), 805-821. https://doi.org/10.1016/j.cie.2018.11.019 